\title{
Formulation and evaluation of topical herbal gel for the treatment of arthritis in animal model
}

\author{
Rajasekaran Aiyalu*, Arulkumaran Govindarjan, Arivukkarasu Ramasamy
}

KMCH College of Pharmacy, Coimbatore, Tamilnadu, India

\begin{abstract}
The objective of the study is to formulate and evaluate a topical herbal gel containing Cardiospermum halicacabum and Vitex negundo leaf extracts for their anti-arthritic activity in rats. Twelve herbal gel formulations were prepared using 1.5\% of gelling agents carbopol 934 (F1-F6) and carbopol 940 (F6-F12) and they were evaluated for physical appearance, net content, viscosity, extrudability, $\mathrm{pH}$, spreadability, in vitro diffusion profile and primary skin irritation tests. The stability study for the topical herbal gel formulation was done as per ICH guidelines and anti-arthritic activity was evaluated by Freund's Complete Adjuvant (FCA) induced arthritis method. Assessment of body weight, paw volume, hematological and biochemical parameters, histopathological examination and In vitro determination of serum biomarkers were also carried out. Formulated gels were homogenous, stable and complied with the guidelines. Among the formulations, F4 showed better release $(98.4 \%)$ characteristics than other formulations. No erythema or edema was observed in the skin irritation test confirming the gel was nontoxic and safe. Topical application of the herbal gel F4 containing carbopol 934 displayed significant (p $<0.001)$ anti-arthritic activity compared to diseased rats. Reduction in paw volume, no agglutination in $\mathrm{C}$ - reactive protein and rheumatic factor, reduction in TNF $\alpha$ level, regaining of normal hematological, and biochemical parameters, reduction in spleen and thymus weight and histopathological examination supported the anti-arthritic activity of the gel formulation.
\end{abstract}

Uniterms: Arthritis/treatment/herbal gel. Cardiospermum halicacabum/topical herbal gel. Vitex negundo/ topical herbal gel. Medicinal plants/arthritis.

\section{INTRODUCTION}

Arthritis is an auto immune disorder that affects about $0.5-1 \%$ of the population worldwide. The drugs commonly prescribed for Rheumatoid Arthritis are steroidal, nonsteroidal anti-inflammatory, disease modifying antirheumatic and immunosuppressant drugs that are known to produce various side effects including gastrointestinal disorders, immunodeficiency and humoral disturbances. The Siddha and Ayurvedic systems of treatment are being increasingly recognized as an alternate approach for the arthritic treatment. The two plants most commonly used in traditional practice for the treatment of arthritis are Cardiospermum halicacabum and Vitex negundo.

Cardiospermum halicacabum (CH) (Sapindaceae) has been used in Chinese medicine for a long time in the

\footnotetext{
*Correspondence: R. Aiyalu. Professor of Pharmaceutical Chemistry. $\mathrm{KMCH}$ College of Pharmacy. Kovai Estate, Kalapatti Road, Coimbatore - 641048. Tamilnadu, India. E-mail: rsekaran2001in@yahoo.co.in
}

treatment of inflammation, rheumatism and in various diseases (Jeyadevi et al., 2013). The anti-inflammatory activity of ethanol extract of $\mathrm{CH}$ reported to inhibit LPS induced COX-2, TNF- $\alpha$ and iNOS expression in RAW264.7 cells (Sheeba, Asha, 2009). Experimental pharmacological studies have shown the analgesic and vasodepressant activities (Gopalakrishnan, Dhananjayan, Kameswaran, 1976), anti-pyretic activity against yeastinduced pyrexia in rats (Asha, Pushpangadan, 1999), anti-malarial (Waako et al., 2005), anti-oxidant activity (Kumaran, Karunakaran, 2006), anti-ulcer activity against ethanol induced gastric ulcer in rats (Sheeba, Asha, 2006) and suppression of the production of TNF- $\alpha$ and nitric oxide in human peripheral blood mononuclear cells (Babu, Krishnakumari, 2006). A number of compounds have been isolated and identified in $\mathrm{CH}$, viz. arachidic acid, apigenin, apigenin-7-O-glucuronide, chrysoeriol-7-O-glucuronide and luteolin-7-O-glucuronide (Subramanyam et al., 2007). Vitex negundo Linn. (Verbenaceae) (VN) known as Nirgundi in Hindi, grows gregariously in wastelands and is 
also planted as a hedge-plant containing several flavonoids such as casticin, orientin, isoorientin, luteolin, lutecin-7O-glucoside, corymbosin, glycosidic iridoids, alkaloids and terpenoids (Nair, Mohenan, 1998). VN has been documented for potent anti-arthritic (Tamhankar, Saraf, 1994), anti-inflammatory, anti-pyretic (Telang, Chatterjee, Varshneya, 1999), anti-convulsant (Gupta, Mazumder, Bhawal, 1999), hepatoprotective and bronchial relaxant (Nair, Mohenan, 1995). They are also used as tonics, vermifuge, lactagogue, emmenagogue, anti-bacterial, antipyretic and anti-histaminic agents (Ghosh, 1984).

There is no report on preclinical studies of $\mathrm{CH}$ and VN on topical gel for its anti-arthritic activity and hence a topical herbal gel was developed using $\mathrm{CH}$ and $\mathrm{VN}$ and evaluated for anti-arthritic activity, to explore the scientific proof for the use of these plants in the treatment of arthritis. $\mathrm{CH}$ and $\mathrm{VN}$ was formulated in the form gel as the administration of gel is easy, causes localized effect, no pain or irritation during application, no first pass effect and no GIT degradation and can be delivered directly on to the affected area.

Though all parts of $\mathrm{CH}$ and $\mathrm{VN}$ are used as medicine, leaves are used majorly for treating arthritis in traditional medicine (Kumar et al., 2008) and hence topical gel formulation was designed using the leaf extracts of both the plants.

\section{MATERIAL AND METHODS}

\section{Material}

The mature fresh leaves of Vitex negundo and Cardiospermum halicacabum were collected from Palakkad, Kerala, and authenticated by GVS Murthy, Director of Botanical Survey of India, Coimbatore. Freund's complete adjuvant (FCA), diclofenac sodium, triethanolamine, propylene glycol and disodium edetate were purchased from Sigma-Aldrich USA. Carbopol 934 and carbopol 940 were obtained from Loba Chemie Pvt. Ltd. Mumbai.

\section{Preparation of extracts}

The leaves of Vitex negundo and Cardiospermum halicacabum were processed to remove earthy matter and residual materials carefully from the leaves, then cleaned and shade dried. Coarse powdered leaves of Cardiospermum halicacabum was extracted in a Soxhlet extractor with methanol for $72 \mathrm{~h}$. Coarse powdered leaves of Vitex negundo was extracted with methanol by cold maceration process for 7 days. Both the extracts were then filtered and concentrated under reduced pressure in IKA Rotary evaporator (Model No RN 10 digital V, ILMAC Germany) at $40{ }^{\circ} \mathrm{C}$ and stored at $4-8{ }^{\circ} \mathrm{C}$ for further use.

\section{Animals}

Wistar strains rats (12-week old healthy) weighing 150-200 $\mathrm{g}$ of either sex in the animal house of $\mathrm{KMCH}$ college of Pharmacy, Coimbatore, Tamil Nadu, India were selected for anti-arthritic evaluation. Female albino mice weighing 20-30 g were used for acute toxicity study and albino rabbits (average weight $2.2 \mathrm{~kg}$ ) were used for primary skin irritation test. They were housed under controlled conditions of temperature $(23 \pm 2){ }^{\circ} \mathrm{C}$, humidity (50 \pm 5$) \mathrm{RH}$ and 10-14 $\mathrm{h}$ light and dark cycles. The animals were housed individually in polypropylene cages containing sterile paddy husk bedding and free access to food and water ad libitum.

The experiments were designed and conducted in accordance with ethical norms approved by Committee for the Purpose of Control and Supervision on Experiments on Animals (CPSCEA) and Institutional Animal Ethical Committee (KMCRET/DRDO/01/2011, dt.16/07/2011).

\section{Preparation of gel base}

Carbopol 934 was dissolved slowly with stirring in $60 \mathrm{~mL}$ of demineralized water for $1 \mathrm{~h}$ to avoid agglomeration Then disodium edetate and triethanolamine were dissolved in $10 \mathrm{~mL}$ of demineralized water separately and stirred for $10 \mathrm{~min}$. Mixed $4.83 \mathrm{~mL}$ of propylene glycol in $12 \mathrm{~mL}$ of demineralized water with stirring for $10 \mathrm{~min}$. Disodium edetate and triethanolamine solution were added to carbopol solution and the $\mathrm{pH}$ was then adjusted to 7.4 by stirring the solution for $10 \mathrm{~min}$. Then propylene glycol solution was added with stirring for 10 min until a clear consistent gel base was obtained.

\section{Preparation of gel formulation}

Twelve topical gel formulation was prepared using CHME (methanol leaf extract of Cardiospermum halicacabum ) and VNME (methanol leaf extract of Vitex negundo) as per drug formulation manual where F1 to F6 formulations were made using the gel base of carbopol 934 $(1.5 \%)$ and F7 to F12 formulations were made using the gel base of carbopol 940 (1.5\%). Details of formulation compositions are recorded in Table I.

The F4 formulation prepared using carbopol 934 was evaluated for anti-arthritic activity as it exhibited better quality characteristics. 
TABLE I - Gel formulations with carbopol 934 and carbopol 940

\begin{tabular}{|c|c|c|c|c|c|c|c|c|}
\hline Gel code & $\begin{array}{c}\text { Cardiospermum } \\
\text { halicacabum extract } \\
\text { (g) }\end{array}$ & $\begin{array}{c}\text { Vitex } \\
\text { negundo } \\
\text { extract (g) }\end{array}$ & $\begin{array}{c}\text { Carbopol } \\
934 \\
(\mathrm{~g}) \\
\end{array}$ & $\begin{array}{c}\text { Carbopol } \\
940 \\
(\mathrm{~g}) \\
\end{array}$ & $\begin{array}{l}\text { Triethanol } \\
\text { amine } \\
\text { (g) }\end{array}$ & $\begin{array}{l}\text { Disodium } \\
\text { EDTA } \\
(\mathrm{g}) \\
\end{array}$ & $\begin{array}{l}\text { Propylene } \\
\text { Glycol } \\
\text { (g) } \\
\end{array}$ & $\begin{array}{l}\text { D.M. water } \\
\quad(100 \mathrm{~g})\end{array}$ \\
\hline$\overline{\mathrm{F} 1}$ & 0.5 & 0.5 & 1.5 & --- & 1.5 & 0.005 & 5 & q.s \\
\hline $\mathrm{F} 2$ & 1 & 1 & 1.5 & ---- & 1.5 & 0.005 & 5 & q.s \\
\hline F3 & 1.5 & 1.5 & 1.5 & ---- & 1.5 & 0.005 & 5 & q.s \\
\hline $\mathrm{F} 4$ & 2 & 2 & 1.5 & ---- & 1.5 & 0.005 & 5 & q.s \\
\hline F5 & 2.5 & 2.5 & 1.5 & --- & 1.5 & 0.005 & 5 & q.s \\
\hline F6 & 3 & 3 & 1.5 & ---- & 1.5 & 0.005 & 5 & q.s \\
\hline F7 & 0.5 & 0.5 & --- & 1.5 & 1.5 & 0.005 & 5 & q.s \\
\hline F8 & 1 & 1 & --- & 1.5 & 1.5 & 0.005 & 5 & q.s \\
\hline F9 & 1.5 & 1.5 & ---- & 1.5 & 1.5 & 0.005 & 5 & q.s \\
\hline F10 & 2 & 2 & ---- & 1.5 & 1.5 & 0.005 & 5 & q.s \\
\hline F11 & 2.5 & 2.5 & ---- & 1.5 & 1.5 & 0.005 & 5 & q.s \\
\hline $\mathrm{F} 12$ & 3 & 3 & --- & 1.5 & 1.5 & 0.005 & 5 & q.s \\
\hline
\end{tabular}

\section{Quality control of topical herbal gel formulation}

\section{Estimation of active constituents in gel formulation (net content)}

Each formulation $(1 \mathrm{~g})$ was taken in a $50 \mathrm{~mL}$ volumetric flask and made up to volume with methanol and shaken well to dissolve the active constituents in methanol. The solution was filtered through Whatman filter paper and $0.1 \mathrm{~mL}$ of the filtrate was pipetted out and diluted to $10 \mathrm{~mL}$ with methanol. The content of active constituents was estimated spectro photometrically by using standard curve plotted at $275 \mathrm{~nm}\left(\lambda_{\max }\right.$ of active constituents in the extracts) (Nandgude et al., 2008).

\section{Extrudability}

A closed collapsible tube containing about $20 \mathrm{~g}$ of gel was pressed firmly at the crimped end and a clamp was applied to prevent any roll back. The cap was removed and the gel was extruded. The amount of the extruded gel was collected and weighed. The percentage of the extruded gel was calculated (Nappinai, Pakalapati, Arimilli, 2006).

\section{pH measurement}

$\mathrm{pH}$ measurement of the gel was carried out using a digital $\mathrm{pH}$ meter by dipping the glass electrode completely into the gel system to cover the electrode. The measurement was carried out in triplicate and the average of the three readings was recorded (Queiroz et al., 2009).

\section{Appearance and Homogeneity}

Physical appearance and homogeneity of the prepared gels were evaluated by visual perception.
Viscosity

Viscosity of gel was determined using Brookfield viscometer (S-62, model LVDV-E) at $25^{\circ} \mathrm{C}$ with a spindle speed of the viscometer rotated at $12 \mathrm{rpm}$ (Nayak et al., 2005).

\section{Spreadability}

Two sets of glass slides of standard dimensions were taken. The herbal gel formulation was placed over one of the slides. The other slide was placed on the top of the gel, such that the gel was sandwiched between the two slides in an area occupied by a distance of $7.5 \mathrm{~cm}$ along the slides. Hundred g weight of gel was placed on the upper slides so that the gel was between the two slides was pressed uniformly to form a thin layer. The weight was removed and the excess of gel adhering to the slides was scrapped off. The two slides in position were fixed to a stand without slightest disturbance and in such a way that only upper slides to slip off freely by the force of weight tied on it. A $20 \mathrm{~g}$ weight was tied to the upper slide carefully. The time taken for the upper slide to travel the distance of $7.5 \mathrm{~cm}$ and separated away from the lower slide under the influence of the weight was noted. The experiment was repeated for three times and the mean time was taken for calculation. (Jain et al., 2007).

Spreadability was calculated by using the following formula:

$$
\mathrm{S}=\mathrm{m} \times 1 / \mathrm{t}
$$

where, $\mathrm{S}=$ spreadability, $\mathrm{m}$-weight tied to upper slides $(20 \mathrm{~g}), 1$ - length of the glass slide $(7.5 \mathrm{~cm})$, t- time taken in sec. 


\section{In vitro diffusion profile}

\section{In vitro permeation in rat skin}

In vitro diffusion studies for all formulations were carried out using Franz diffusion cell. The diffusion cell apparatus was fabricated locally as open-ended cylindrical tube with $3.7994 \mathrm{~cm}^{2}$ area and $100 \mathrm{~mm}$ height having a diffusion area of $3.8 \mathrm{~cm}^{2}$. Phosphate buffer (pH 7.4) was used as receptor media. Rat abdominal skin was used as dialysis membrane. The skin was tied to the diffusion cell (donor cell) such that the stratum corneum side of the skin was in intimate contact with the release surface of the formulation in the donor cell. Isotonic phosphate buffer solution, $\mathrm{pH} 7.4(100 \mathrm{~mL})$ was added to a donor compartment prior to be mounted on the diffusion cell. A weighed quantity of formulation equivalent to $1 \mathrm{~g}$ of gel was taken on to the rat skin and was immersed slightly in $100 \mathrm{~mL}$ of receptor medium, which was continuously stirred. The entire system was maintained at $37 \pm 1{ }^{\circ} \mathrm{C}$. An aliquot of $5 \mathrm{~mL}$ was withdrawn at specific time intervals up to $8 \mathrm{~h}$, and was estimated spectrophotometrically at $275 \mathrm{~nm}$. After each withdrawal, the diffusion medium was replaced with an equal volume of fresh diffusion medium. The cumulative percent release was calculated for each time (in h) interval.

\section{Release kinetics}

To find out the release pattern of active constituent from herbal gel, data obtained were fitted to different mathematical models (Martin, 1994). Zero order kinetics is a concentration independent kinetics and first order kinetics is the dependent kinetics, where drug release may follow swelling and erosion or simply diffusion. Data were validated using Higuchi's model to ascertain the reaction.

\section{Stability studies of topical herbal gel formulation}

The main objective of the stability testing is to provide evidence on how the quality of the drug product varies with time under the influence of temperature and humidity. The stability study for the topical herbal gel formulation was done as per ICH guidelines in a stability chamber for a period of 6 months. The selected topical herbal gel formulation consisting of $2 \%$ of each CHME and VNME was loaded in a humidity chamber (Floor standing model, 3 units in one with individual humidity and temperature controller, $300 \times 300 \times 300 \mathrm{~mm}, 15-$ $60^{\circ} \mathrm{C}$, Technico, India) at $25^{\circ} \mathrm{C} \pm 2{ }^{\circ} \mathrm{C} / 60 \% \mathrm{RH} \pm 5 \% \mathrm{RH}$, $32{ }^{\circ} \mathrm{C} \pm 2{ }^{\circ} \mathrm{C} / 60 \% \mathrm{RH} \pm 5 \% \mathrm{RH}$ and $40^{\circ} \mathrm{C} \pm 2{ }^{\circ} \mathrm{C} / 75 \% \mathrm{RH}$ $\pm 5 \%$ RH. Samples were withdrawn at an initial, first, second, third and sixth months and evaluated for change in color, odor, homogeneity, $\mathrm{pH}$, viscosity, net content, microbial load and sterility test.

\section{Anti-arthritic activity}

Efficacy of the topical herbal gel formulation was studied by FCA induced arthritis model (Mizushima, Tsukada, Akimoto, 1972) in rats through topical application. The rats were divided into four groups, each consisting of six animals. Group 1 was applied topically with gel base considered as normal control. Arthritis was induced to group 2 to 4 by injecting a $0.1 \mathrm{~mL}(0.1 \% \mathrm{w} / \mathrm{v})$ suspension of killed Mycobacterium tuberculosis bacteria (Genei, Bangalore) homogenized in liquid paraffin into the left hind foot in the subplantar region of rats. Group 2 was considered as arthritic control. Groups 2 to 4 administered with FCA were allowed to develop arthritis for 21 days. During the experimental period, body weight and the rat paw volume of control and treatment groups were measured on $4^{\text {th }}, 8^{\text {th }}, 14^{\text {th }}$ and $21^{\text {st }}$ day by using digital Vernier caliper (Mitetoyo digimatic caliper, Japan).

After the confirmation of arthritis development, diclofenac sodium gel (Voveran gel, purchased from community pharmacy shop) and the herbal gel formulation F4 were applied topically for 22 to 42 days to the left knee joint region of Group 3 (served as reference standard) and groups 4 respectively.

During the treatment period, the body weight of the animals and the rat paw volume of control and treatments were measured on $25^{\text {th }}, 29^{\text {th }}, 35^{\text {th }}$ and $42^{\text {nd }}$ days by using digital Vernier caliper (Mitetoyo digimatic caliper, Japan). At the end of $42^{\text {nd }}$ day the pain test score of the animals were recorded visually (Laird et al., 2001).

\section{Hematological parameters}

The overnight fasted animals were anaesthetized with ketamine $(20 \mathrm{mg} / \mathrm{kg}$, i.p $)$ followed by withdrawal of blood samples from retro-orbital sinus and the collected blood samples were centrifuged at $10000 \mathrm{rpm}$ for 10 min and evaluated for hematological parameters viz. Hematological parameters like red blood cell (RBC) count, white blood cell (WBC) count, hemoglobin $(\mathrm{Hb})$ value, erythrocyte sedimentation rate (ESR) were evaluated using routine laboratory methods (Patil, Patil, Jadhav, 2009). The separated serum was analyzed for urea, uric acid and serum biomarkers viz. CRP, RF (Omega diagnostics Limited, Scotland, UK), TNF $\alpha$ (ELISA Kit, Gen-Probe, France), IL-1ß and IL6 (ELISA Kit, R\&D systems, USA).

\section{Biochemical estimations}

A portion of the blood samples were centrifuged at $10000 \mathrm{rpm}$ for $10 \mathrm{~min}$ and the separated serum was 
analyzed for biochemical parameters viz. Cholesterol, triglycerides, VLDL levels SGOT, SGPT, ALP, total bilirubin, total protein, albumin, globulin, urea, uric acid and creatinine. Biochemical investigations were carried out in a autoanalyser (Photometer 5010 V5+, Robert Riely, Berlin) using Piramal healthcare limited reagent kit.

\section{Histopathological investigations}

The animals were sacrificed by cervical dislocation and the organs thymus, spleen and bone joints of ankle joint were isolated and weighed after separating the superficial fat. The isolated ankle joint was immersed for 9 days in Cal-Ex Decalcifying solution CSS10-1D (Fischer Scientific, India). The ankle joint was then embedded in paraffin, sectioned serially $(6 \mu)$ using microtome, mounted on a microscope slides and stained with Harris hemotoxylin and Eosin (Murphy et al., 2003). Histopathological changes in the joints rats were examined under microscope and digital images were acquired.

\section{Statistical analysis}

All the data expressed as mean \pm SEM were evaluated by one-way analysis of variance (ANOVA), followed by Dunnett's test for multiple comparisons using prism Graphpad version 5.0 and values of $\mathrm{P}<0.05$ were considered as statistically significant.

\section{Skin irritation study}

Three young adult rabbits were housed in metal cages fitted with perforated floors. Water and standard rabbit feed were given ad libitum. The room temperature was maintained at $22 \pm 3{ }^{\circ} \mathrm{C}$ with $30-70 \%$ relative humidity. The light conditions were controlled to give $12 \mathrm{~h}$ artificial light ( $8 \mathrm{am}-8 \mathrm{pm}$ ) each day. Twenty four $\mathrm{h}$ before the test (dose application), hair on the back and flanks of each rabbit were shaved cleanly, exposing approximately $6 \mathrm{~cm}^{2}$ area of skin. The final gel formulation was evenly applied to $4 \mathrm{~cm}^{2}$ area of the closely clipped skin of each rabbit. Skin reaction at the site of application was subjectively assessed and scored once daily at 1, 24, 48, $72 \mathrm{~h}, 7$ and 10 days (post test observation period) accordingly.

\section{RESULTS AND DISCUSSION}

In general, gel formulation is more preferred, among the other topical semisolid preparations, since it has long residence time on the skin, high viscosity, moisturizing effect on flaky skin due to their occlusive properties, more bio adhesiveness, less irritation, independent of water solubility of active ingredient, ease of application and better release characters (Loganathan et al., 2001). Many studies have indicated that flavonoids such as luteolin and apigenin in herbs possess anti-inflammatory and antiarthritic activity. Further, these polyphenolic flavonoids, apigenin and luteolin reported that they can penetrate the human skin (Giinter et al., 2008) and hence a topical herbal gel formulation was designed containing these flavonoids for the treatment of arthritis.

\section{Formulation and evaluation of topical herbal gel}

Twelve different gel formulations (F1 to F12) were prepared using different concentrations $(0.5,1,1.5,2$, 2.5 and $3 \% \mathrm{w} / \mathrm{w}$ ) of methanol extract of Cardiospermum halicacabum and Vitex negundo, with $1.5 \%$ concentration of Carbopol 934 or Carbopol 940 polymer respectively. Carbopol 934 and carbopol 940 were used as gelling agent in the formulation as they are biodegradable, bioadhesive, biocompatible, irritation free and not absorbed into body.

Among the two polymers used, carbopol 934 was reported to have more gelling property than carbopol 940 (Blonco-Flonte et al., 1996), which is in correlation with our study. Carbopol 934 polymer proved to be a promising carrier for controlled release of active phytoconstiuents in the gel formulation.

The percentage of polymer was optimized after preparing the gel with various concentrations from 0.5 to $2.5 \%$, where the $1.5 \%$ of carbopol (934 or 940 ) containing gels was found to be compatible with the requirements of gel formulations.

From the quality control test, it was apparent that the gel formulations prepared with Carbopol 934 (F1 to F6) as a gelling agent were found to be superior to the gel formulations prepared with Carbopol 940 (F7 to F12) except only spreadability parameters where Carbopol 940 was found to be good. Hence the in vitro diffusion studies were carried out only for the six herbal topical gel preparations F1 to F6, formulated using carbopol 934 and the in vitro release and stability studies were carried out for the best herbal gel formulation F4.

Dimethylsulfoxide and propylene glycol are reported to be the two best permeation enhancers (Panigrahi et al., 2006). Since DMSO reported to causes skin erosion we have used propylene glycol as permeation enhancer in the preparation of the gel formulation (Walker, Smith, 1996). Disodium edetate and triethanolamine were used in the formulation in order to adjust the $\mathrm{pH}$ of the formulation. 
Quality control test for formulated topical herbal gel

Twelve gel formulations F1 to F12 prepared using carbopol polymers were evaluated for physical appearance, $\mathrm{pH}$, viscosity, spreadability, net content, extrudability and in vitro diffusion profile. Results of the study were in acceptable limits of the ICH guidelines and the details of the same are recorded in Table II.

Prepared gels were found to be homogeneous and in good appearance and consistency. The $\mathrm{pH}$ values of all the formulations were in the close range of neutral $\mathrm{pH}$ (7.42-7.88) and hence it caused no skin irritation, which is also supported by skin irritation study.

Polymers were included in the designed topical formulations in order to provide a prompt release of drug and to achieve as well as to maintain the drug concentration within the therapeutically effective range. As the concentration of the polymer was fixed as $1.5 \%$ in all the gel formulations no variation in viscosity was observed. Further the value between 0.38 and 0.39 poise was reported to be an ideal viscosity value for topical gel formulation developed using carbopol polymers (Kim et al., 2003).

Values of the spreadability indicated that the gel formulations are easily spreadable. Among the gel formulations $\mathrm{F} 1$ to $\mathrm{F} 6$, more than $90 \%$ of the contents were extrudable indicating they have excellent extrudability except $\mathrm{F} 1$ and $\mathrm{F} 3$ as $80 \%$ of the contents were extrudable ( $>90 \%$ extrudability: excellent, $>80 \%$ extrudability: good, $>70 \%$ extrudability: fair).

\section{In vitro diffusion profile and release kinetics}

In vitro diffusion profile of $\mathrm{F} 1$ to $\mathrm{F} 6$ formulations are recorded in Figure 1. Since the $\mathrm{pH}$ of membrane used was in the range of 5 to 7.8 , phosphate buffer saline $\mathrm{pH} 7.4$ was used for the in vitro release studies of the gel formulations. The in vitro release profiles of all the six formulations made using carbopol 934 elicited almost $100 \%$ release from the formulation within $5 \mathrm{~h}$.

The in vitro release characteristics of the prepared topical herbal gel formulations were quite encouraging and in agreement with marketed diclofenac gel.

Among the formulations, $\mathrm{F} 4$ showed better release $(98.4 \%)$ characteristics than F1, F2, F3, F5 and F6 (Figure 2 to 4 )

Based on our kinetic release study, we observed that

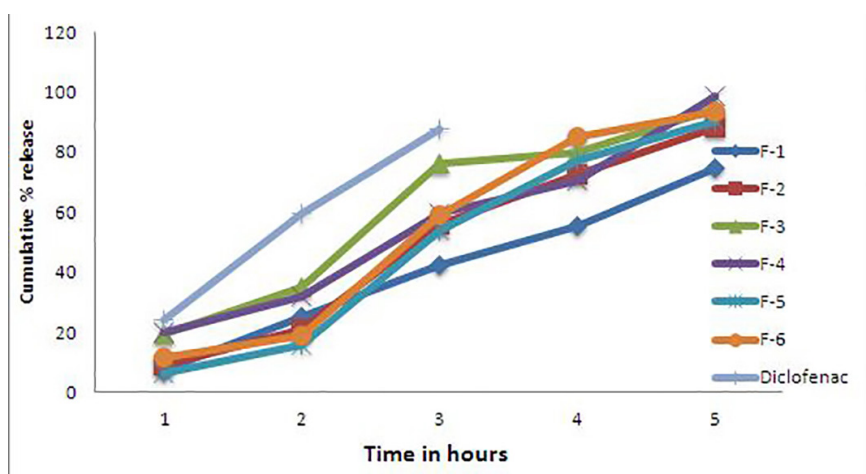

FIGURE 1 - In vitrodiffusion profile of topical herbal gels (F1-F6) and diclofenac sodium gel.

TABLE II - Evaluation parameters for topical herbal gel formulation made with 1.5\% Carbopol 934

\begin{tabular}{|c|c|c|c|c|c|c|c|}
\hline Code & Conc $(\%)$ & $\mathrm{pH}^{*}$ & $\begin{array}{l}\text { Viscosity* } \\
\text { (poise) }\end{array}$ & $\begin{array}{l}\text { Spreadability* } \\
\text { g cm/sec }\end{array}$ & $\begin{array}{c}\text { Net } \\
\text { content* } \\
\% \mathrm{w} / \mathrm{w}\end{array}$ & Extrudability* & Physical appearance \\
\hline$\overline{\mathrm{F} 1}$ & 0.5 & 7.57 & 0.3850 & 32.19 & 99.7 & Good & $\begin{array}{l}\text { Greenish, smooth and } \\
\text { translucent }\end{array}$ \\
\hline $\mathrm{F} 2$ & 1.0 & 7.57 & 0.3862 & 45.05 & 105 & Excellent & $\begin{array}{c}\text { Dark green, smooth, } \\
\text { homogenous, translucent }\end{array}$ \\
\hline F 3 & 1.5 & 7.79 & 0.3873 & 56.39 & 105 & Good & $\begin{array}{c}\text { Dark green, smooth, } \\
\text { homogenous, translucent }\end{array}$ \\
\hline F 4 & 2.0 & 7.60 & 0.3882 & 64.00 & 105 & Excellent & $\begin{array}{l}\text { Dark green, smooth, } \\
\text { homogenous, translucent }\end{array}$ \\
\hline F 5 & 2.5 & 7.88 & 0.3891 & 71.38 & 101 & Excellent & $\begin{array}{c}\text { Dark green, smooth, } \\
\text { homogenous, translucent }\end{array}$ \\
\hline F 6 & 3.0 & 7.42 & 0.3906 & 75.74 & 101 & Excellent & $\begin{array}{l}\text { Dark green, smooth, } \\
\text { homogenous, translucent }\end{array}$ \\
\hline
\end{tabular}

*Values mentioned are the average of five determinations 


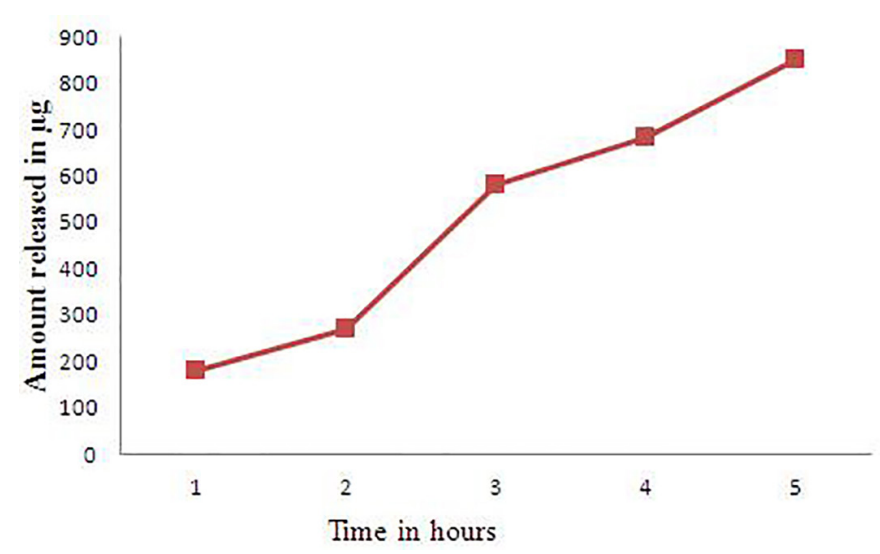

FIGURE 2 - Zero order plot for F4 topical herbal gel formulation.

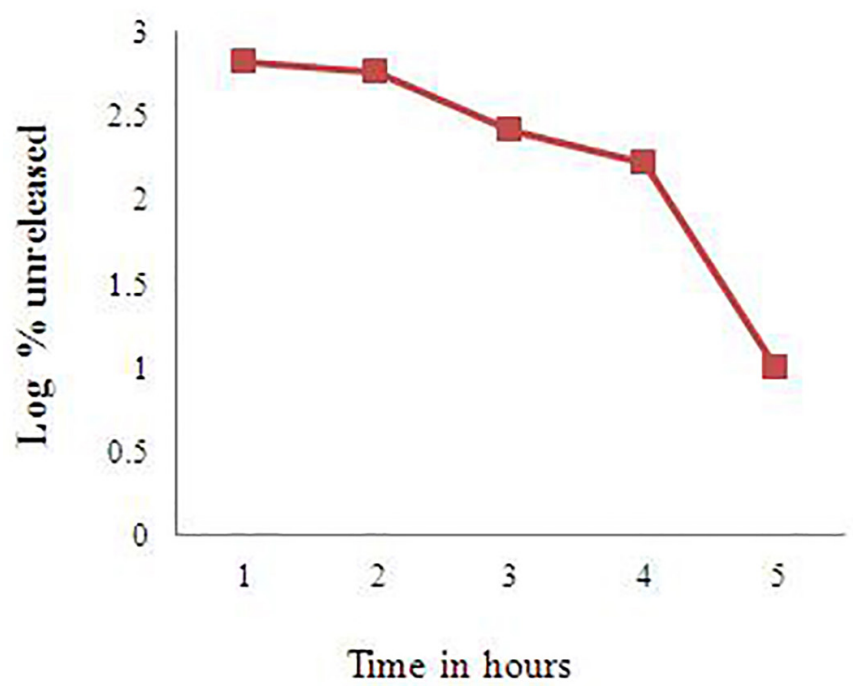

FIGURE 3 - First order plot for F4 topical herbal gel formulation.

the F4 formulation followed zero order kinetics. Since zero order kinetics is preferred for sustained release, gel formulation containing $2 \%$ each of CHME and VNME was selected for in vivo studies. Commercial diclofenac sodium gel formulation released almost $90 \%$ of its content within $3 \mathrm{~h}$, whereas $\mathrm{F} 4$ formulation consisting of $2 \%$ each

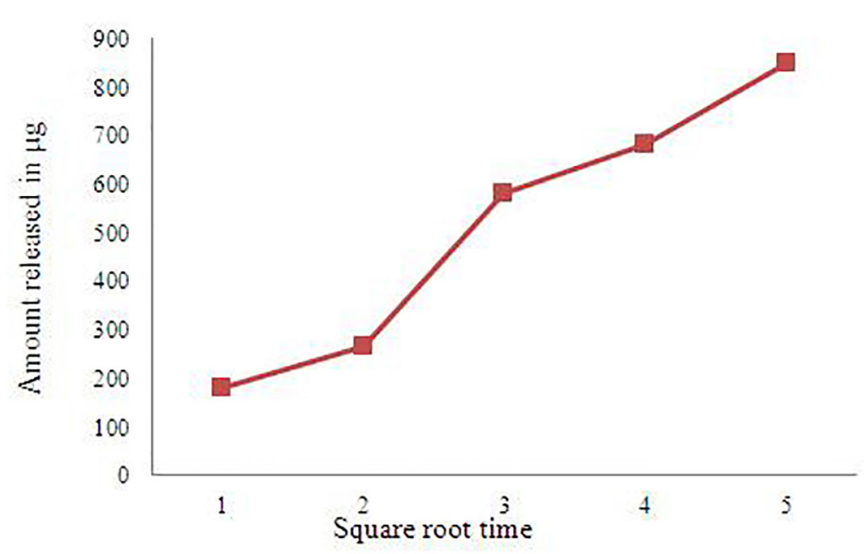

FIGURE 4 - Higuchi diffusion plot for F4 topical herbal gel formulation.

of CHME and VNME prolonged its release of active constituents up to $5 \mathrm{~h}$ (almost 100\%), making it suitable for sustained release and for better patient compliance. Thus from the release data observed using different mathematical models, gel formulation containing $2 \%$ of each of CHME and VNME showed zero order release kinetics (Table III). Since zero order kinetics follows controlled release, the gel formulation F4 containing 2\% each of CHME and VNME was selected for in vivo studies

\section{Skin irritation test}

The prepared herbal gel was evaluated for its skin irritant effect, where no erythema or edema was observed for all the formulations (Table IV), even after 10 days of study, indicating that the prepared herbal gel formulation was found to be safe.

\section{Stability testing}

In order to ensure the quality, safety and efficacy throughout the shelf life, stability study was performed as per ICH guidelines for F4 formulation (prepared using

TABLE III - In vitro release kinetic study of topical herbal gel formulated with Carbopol 934

\begin{tabular}{lcccc}
\hline $\begin{array}{l}\text { Formulation } \\
\text { code }\end{array}$ & $\begin{array}{c}\text { Zero order } \\
\mathbf{R}^{\mathbf{2}}\end{array}$ & $\begin{array}{c}\text { First Order } \\
\mathbf{R}^{\mathbf{2}}\end{array}$ & $\begin{array}{c}\text { Higuchi diffusion model } \\
\mathbf{R}^{\mathbf{2}}\end{array}$ & $\begin{array}{c}\text { Best fitted } \\
\text { model }\end{array}$ \\
\hline F1 & 0.969 & 0.911 & $>1$ & Zero order \\
F2 & 0.954 & 0.947 & 0.936 & Zero order \\
F3 & 0.924 & 0.933 & $>1$ & First order \\
F4 & 0.989 & 0.913 & $>1$ & Zero order \\
F5 & 0.900 & 0.907 & 0.909 & Higuchi \\
F6 & 0.912 & 0.892 & 0.917 & Higuchi \\
\hline
\end{tabular}


carbopol 934) as it exhibited better quality characteristics. No change in color, odour, homogeneity, $\mathrm{pH}$, viscosity and net content of the topical herbal gel formulation was observed for this formulation after $0,1,2,3$ and 6 months of stability testing. Results of the study clearly revealed that the formulated topical gel F4 is found to be stable (Table V).

\section{Body weight}

The average gain/reduction in body weight was observed for all the groups after induction of arthritis in rats (Table VI). Reduction in body weight was observed for arthritic control group whereas gain in body weight was observed in diclofenac sodium gel and topical herbal

TABLE IV- Primary skin irritation test for herbal gel formulation 940 and 934

\begin{tabular}{|c|c|c|c|c|c|c|}
\hline & \multicolumn{3}{|c|}{ Rabbit Numbers } & \multicolumn{2}{|c|}{ Rabbit } & \multirow{2}{*}{$\begin{array}{l}\text { Combined } \\
\text { index }\end{array}$} \\
\hline & 1 & 2 & 3 & Control & Average & \\
\hline \multicolumn{7}{|l|}{$\overline{1 \mathrm{~h}}$} \\
\hline Erythema Score & 0 & 0 & 0 & 0 & 0.00 & 0.00 \\
\hline Edema Score & 0 & 0 & 0 & 0 & 0.00 & \\
\hline \multicolumn{7}{|l|}{$24 \mathrm{~h}$} \\
\hline Erythema Score & 0 & 0 & 0 & 0 & 0.00 & 0.00 \\
\hline Edema Score & 0 & 0 & 0 & 0 & 0.00 & \\
\hline \multicolumn{7}{|l|}{$48 \mathrm{~h}$} \\
\hline Erythema Score & 0 & 0 & 0 & 0 & 0.00 & 0.00 \\
\hline Edema Score & 0 & 0 & 0 & 0 & 0.00 & \\
\hline \multicolumn{7}{|l|}{$72 \mathrm{~h}$} \\
\hline Erythema Score & 0 & 0 & 0 & 0 & 0.00 & 0.00 \\
\hline Edema Score & 0 & 0 & 0 & 0 & 0.00 & \\
\hline \multicolumn{7}{|l|}{7 days } \\
\hline Erythema Score & 0 & 0 & 0 & 0 & 0.00 & 0.00 \\
\hline Edema Score & & 0 & 0 & 0 & 0 & 0.00 \\
\hline \multicolumn{7}{|l|}{10 days } \\
\hline Erythema Score & 0 & 0 & 0 & 0 & 0.00 & 0.00 \\
\hline Edema Score & 0 & 0 & 0 & 0.00 & & \\
\hline
\end{tabular}

TABLE V- Stability studies of topical herbal gel formulation

\begin{tabular}{|c|c|c|c|c|c|c|c|c|c|c|c|c|c|c|c|c|c|c|}
\hline \multirow{5}{*}{ S.N } & \multirow{5}{*}{ Parameters } & \multicolumn{15}{|c|}{ Topical herbal gel formulation (F4) containing $2 \% \mathrm{w} / \mathrm{v}$ of each CHME and VNME } & \multirow{5}{*}{ 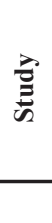 } & \multirow{5}{*}{ 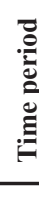 } \\
\hline & & \multicolumn{15}{|c|}{ Storage condition } & & \\
\hline & & \multirow{2}{*}{\multicolumn{5}{|c|}{$\frac{25{ }^{\circ} \mathrm{C} \pm 2{ }^{\circ} \mathrm{C} / 60 \% \mathrm{RH} \pm 5 \% \mathrm{RH}}{\text { Months }}$}} & \multicolumn{5}{|c|}{$32{ }^{\circ} \mathrm{C} \pm 2{ }^{\circ} \mathrm{C} / 60 \% \mathrm{RH} \pm 5 \% \mathrm{RH}$} & \multicolumn{5}{|c|}{$40{ }^{\circ} \mathrm{C} \pm 2{ }^{\circ} \mathrm{C} / 75 \% \mathrm{RH} \pm 5 \% \mathrm{RH}$} & & \\
\hline & & & & & & & \multicolumn{5}{|c|}{ Months } & \multicolumn{5}{|c|}{ Months } & & \\
\hline & & $\mathbf{0}$ & 1 & 2 & 3 & 6 & 0 & 1 & 2 & 3 & 6 & $\mathbf{0}$ & 1 & 2 & 3 & 6 & & \\
\hline 1 & Color & \multicolumn{5}{|c|}{ No change in color } & \multicolumn{5}{|c|}{ No change in color } & \multicolumn{5}{|c|}{ No change in color } & & \\
\hline 2 & Odour & \multicolumn{5}{|c|}{ No change in odour } & \multicolumn{5}{|c|}{ No change in odour } & \multicolumn{5}{|c|}{ No change in odour } & $\Xi$ & $\stackrel{\mathscr{E}}{=}$ \\
\hline 3 & Homogeneity & \multicolumn{5}{|c|}{ Smooth } & \multicolumn{5}{|c|}{ Smooth } & \multicolumn{5}{|c|}{ Smooth } & \pm & $\dot{e}^{e}$ \\
\hline 4 & pH & 6.44 & 6.42 & 6.39 & 6.37 & 6.34 & 6.43 & 6.40 & 6.41 & 6.38 & 6.36 & 6.42 & 6.40 & 6.37 & 6.35 & 6.34 & $\frac{\mathscr{E}}{\mathfrak{n}}$ & $\frac{1}{2}$ \\
\hline 5 & Viscosity (poise) & 0.385 & 0.385 & 0.380 & 0.375 & 0.370 & 0.385 & 0.383 & 0.380 & 0.376 & 0.372 & 0.385 & 0.380 & 0.378 & 0.370 & 0.364 & & \\
\hline 6 & Net content (\%) & 99 & 99 & 98 & 97 & 97 & 99 & 98 & 98 & 97 & 98 & 99 & 97 & 96 & 95 & 95 & & \\
\hline 7 & $\begin{array}{l}\text { Microbial load } \\
\text { (Bacteria \& Fungi) }\end{array}$ & \multicolumn{5}{|c|}{$\begin{array}{l}\text { No microbial growth was observed at } \\
\qquad 24,48 \text { and } 72 \mathrm{~h}\end{array}$} & \multicolumn{5}{|c|}{$\begin{array}{l}\text { No microbial growth was observed at } \\
\qquad 24,48 \text { and } 72 \mathrm{~h}\end{array}$} & \multicolumn{5}{|c|}{$\begin{array}{l}\text { No microbial growth was observed at } \\
\qquad 24,48 \text { and } 72 \mathrm{~h}\end{array}$} & & \\
\hline 8 & Sterility test & \multicolumn{5}{|c|}{$\begin{array}{l}\text { No microbial growth was observed at } \\
\qquad 24,48 \text { and } 72 \mathrm{~h}\end{array}$} & \multicolumn{5}{|c|}{$\begin{array}{l}\text { No microbial growth was observed at } \\
\qquad 24,48 \text { and } 72 \mathrm{~h}\end{array}$} & \multicolumn{5}{|c|}{$\begin{array}{l}\text { No microbial growth was observed at } \\
\qquad 24,48 \text { and } 72 \mathrm{~h}\end{array}$} & & \\
\hline
\end{tabular}


gel formulation F4 treated groups, when compared with the normal group of rats.

\section{Acute oral toxicity study}

A detailed study on acute and sub-chronic toxicity of these plants was already reported by us revealed that the $\mathrm{CH}$ and VN extracts were nontoxic up to the dose of 2000 mg/kg. (Rajasekaran, Arulkumaran, Arivukkarasu, 2015).

\section{Paw volume}

After topical application of diclofenac sodium gel and the herbal gel formulation (F4) from 22 to 42 days, changes in rat paw volume were recorded on $25^{\text {th }}, 29^{\text {th }}$, $35^{\text {th }}$ and $42^{\text {nd }}$ days (Table VII and Figure 5). The arthritic control groups showed signs of arthritis development as seen by increase in paw volume. Significant $(p<0.01)$ reduction in rat paw volume was observed in diclofenac sodium gel treated groups and topical herbal gel formulation F4 treated groups, on $21^{\text {st }}$ day after FCA induction.

The severity of arthritis was assessed by visual arthritic scoring systems described by Laird et al. (2001). The arthritic test scores were assigned as shown in Table VIII revealed that the pain associated with FCA induced arthritis was significantly decreased in diclofenac sodium gel treated and topical herbal gel formulation F4 treated groups. Significant alterations in flexion pain test score, mobility score and stance score was observed for all the treated group of rats when compared with arthritic control rats. This alteration of arthritic test scores support the anti-arthritic activity of the topical herbal gel formulation F4.

Among the formulations F1 to F6, F4 formulation was selected for anti-arthritic study as the results of quality control evaluation of formulation was found to be good and the in vitro release characteristics of the prepared topical gel formulations F4 was quite encouraging and in agreement with marketed diclofenac sodium gel.

TABLE VI - Effect of diclofenac sodium, F4 herbal gel formulation on body weight changes in FCA Induced arthritic rats

\begin{tabular}{|c|c|c|c|c|c|c|c|}
\hline Groups & $\begin{array}{c}\text { Initial body } \\
\text { weight (g) }\end{array}$ & $\begin{array}{l}\text { Body wt after } \\
21 \text { days of FCA } \\
\text { induction }\end{array}$ & $\begin{array}{c}\text { Body wt after } \\
\text { treatment } \\
25^{\text {th }} \text { day }\end{array}$ & $\begin{array}{c}\text { Body wt after } \\
\text { treatment } \\
29^{\text {th }} \text { day }\end{array}$ & $\begin{array}{c}\text { Body wt after } \\
\text { treatment } \\
3^{\text {th }} \text { day }\end{array}$ & $\begin{array}{c}\text { Body wt after } \\
\text { treatment } \\
42^{\text {nd }} \text { day }\end{array}$ & $\begin{array}{c}\text { Weight gain } \\
\text { (g) }\end{array}$ \\
\hline Normal Control & $146.3 \pm 0.84$ & $172.2 \pm 1.70$ & $173.2 \pm 1.89$ & $177.50 \pm 1.54$ & $184.50 \pm 1.12$ & $192.70 \pm 1.25$ & $20.50 \pm 1.89$ \\
\hline Arthritic control & $145.3 \pm 0.84$ & $142.80 \pm 0.79^{\mathrm{a}}$ & $141.20 \pm 0.94^{\mathrm{a}}$ & $138.30 \pm 1.05^{\mathrm{a}}$ & $136.00 \pm 1.13^{\mathrm{a}}$ & $132.70 \pm 1.26^{\mathrm{a}}$ & $-11.00 \pm 1.34$ \\
\hline $\begin{array}{l}\text { Diclofenac } \\
\text { sodium topical } \\
\text { gel }(1 \% \mathrm{w} / \mathrm{w})\end{array}$ & $145.00 \pm 1.15$ & $142.20 \pm 1.25^{\mathrm{a}}$ & $143.00 \pm 1.41^{\mathrm{ns}}$ & $144.20 \pm 1.35^{b}$ & $146.50 \pm 1.83^{\mathrm{a}}$ & $149.80 \pm 1.66^{\mathrm{c}}$ & $7.66 \pm 0.66$ \\
\hline $\begin{array}{l}\text { Topical herbal } \\
\text { gel formulation } \\
(2 \% \mathrm{w} / \mathrm{w})\end{array}$ & $145.5 \pm 1.05$ & $141.70 \pm 1.38^{\mathrm{a}}$ & $142.20 \pm 1.49^{\mathrm{ns}}$ & $143.00 \pm 1.34^{b}$ & $144.80 \pm 1.56^{\mathrm{b}}$ & $147.50 \pm 1.71^{\mathrm{c}}$ & $5.83 \pm 0.47$ \\
\hline
\end{tabular}

Data provided as mean \pm SEM ( $n=6) ;{ }^{a} \mathrm{p}<0.001$ Arthritic control Vs Normal control; ${ }^{b} \mathrm{p}<0.05$ Treated groups Vs Arthritic control; ${ }^{\mathrm{c}} \mathrm{p}<0.001$ Treated Groups Vs Arthritic control

TABLE VII - Evaluation of anti-arthritic activity of herbal gel formulation F4 in FCA induced arthritic rats

\begin{tabular}{|c|c|c|c|c|c|c|}
\hline \multirow{3}{*}{ Groups } & \multicolumn{6}{|c|}{ Rat paw volume (mm) } \\
\hline & \multicolumn{2}{|c|}{ Before treatment } & \multicolumn{4}{|c|}{ After treatment } \\
\hline & Initial & After 21 days & $25^{\text {th }}$ day & $29^{\text {th }}$ day & $35^{\text {th }}$ day & $42^{\text {nd }}$ day \\
\hline Arthritic control & $4.81 \pm 0.12$ & $10.62 \pm 0.15^{\mathrm{a}}$ & $10.65 \pm 0.26^{\mathrm{a}}$ & $10.68 \pm 0.17^{\mathrm{a}}$ & $10.74 \pm 0.23^{a}$ & $10.79 \pm 0.11^{a}$ \\
\hline $\begin{array}{l}\text { Diclofenac sodium topical gel (1 } \\
\% \mathrm{w} / \mathrm{w})\end{array}$ & $5.10 \pm 0.13^{\mathrm{a}}$ & $10.40 \pm 0.15^{\mathrm{a}}$ & $10.47 \pm 0.22^{\mathrm{ns}}$ & $9.81 \pm 0.16^{\mathrm{b}}$ & $8.93 \pm 0.23^{\mathrm{c}}$ & $8.19 \pm 0.07^{\mathrm{c}}$ \\
\hline
\end{tabular}

Data provided as mean \pm SEM $(n=6) .{ }^{a} \mathrm{p}<0.001$ Arthritic control Vs Normal control; ${ }^{b} \mathrm{p}<0.05$ Treated groups Vs Arthritic control ${ }^{\mathrm{c}} \mathrm{p}<0.001$ Treated groups Vs Arthritic control. 


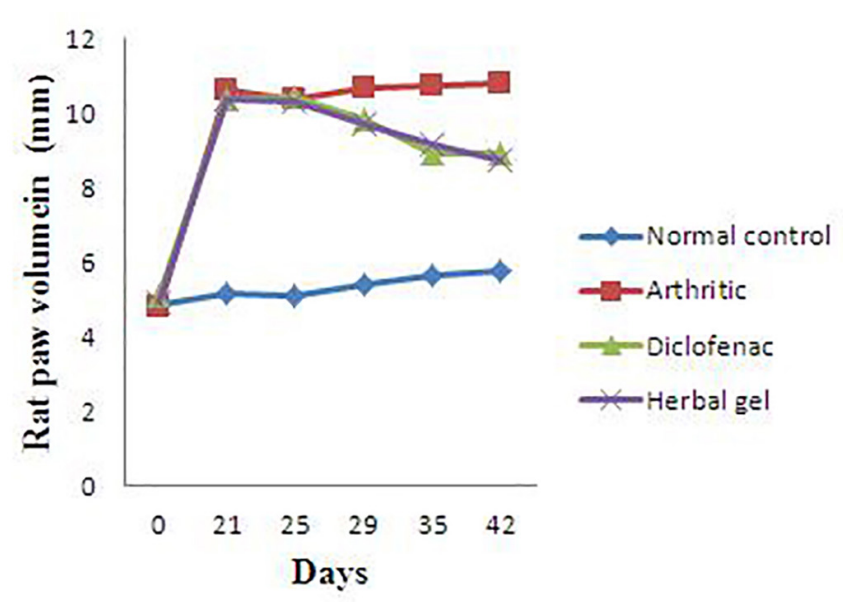

FIGURE 5 - Herbal gel formulation F4 in FCA induced arthritic rats.

FCA-induced arthritis is the most widely used model in which the clinical and pathological changes are comparable with those seen in human rheumatoid arthritis (Tsai, Lin, 1999).

FCA-induced polyarthritis is associated with an immune-mediated inflammatory reaction and the rat is unique in developing polyarthritis after FCA treatment (Nielen et al., 2006).

Selective reduction of arthritic score (Table VIII) and significant reduction in thymus and spleen weight in all the treated groups compared with arthritic rats supported the anti-arthritic activity.

\section{Hematological parameters}

Rats applied with diclofenac sodium gel and herbal gel formulation elicited decrease in WBC count, ESR and increase in $\mathrm{Hb}$ and $\mathrm{RBC}$ count, when compared with arthritic control groups (Table IX).

Characteristic hematological alterations such as increased $\mathrm{Hb}$ and decrease in WBC count was observed after topical application of herbal gel and diclofenac sodium gel. It is proposed that the reduction in the $\mathrm{Hb}$ count during arthritis results from reduced erythropoietin levels, a decreased response of the bone marrow erythropoietin and premature destruction of red blood cells. It has been reported that a moderate rise in the WBC count occurs in arthritic conditions due to an IL-1B mediated rise in the respective colony stimulating factors. The present study reveals that topical herbal gel and diclofenac sodium gel treatments tend to normalize the WBC count.

\section{Biochemical parameters}

Significant $(\mathrm{p}<0.01)$ decrease in urea and uric acid

TABLE VIII - Alterations in various pain test scores in FCA Induced arthritis in rats

\begin{tabular}{|c|c|c|c|c|}
\hline \multirow{2}{*}{ Groups } & \multicolumn{2}{|c|}{ Pain test } & \multirow{2}{*}{ Mobility score } & \multirow{2}{*}{ Stance score } \\
\hline & Extension & Flexion & & \\
\hline Arthritic control & $9.5 \pm 0.34$ & $8.33 \pm 0.33$ & $1.33 \pm 0.21$ & $1.50 \pm 0.22$ \\
\hline $\begin{array}{l}\text { diclofenac sodium } \\
\text { topical gel }(1 \% \mathrm{w} / \mathrm{w})\end{array}$ & $5.16 \pm 0.16^{\mathrm{d}}$ & $4.66 \pm 0.21^{\mathrm{d}}$ & $2.66 \pm 0.21^{\mathrm{d}}$ & $2.33 \pm 0.21^{\mathrm{d}}$ \\
\hline $\begin{array}{l}\text { Topical herbal gel } \\
\text { formulation }(2 \% \mathrm{w} / \mathrm{w})\end{array}$ & $4.66 \pm 0.21^{\mathrm{d}}$ & $3.66 \pm 0.33^{\mathrm{d}}$ & $3.16 \pm 0.21^{\mathrm{d}}$ & $2.83 \pm 0.16^{\mathrm{d}}$ \\
\hline
\end{tabular}

Data provided as mean \pm SEM $(n=6) ;{ }^{\mathrm{d}} \mathrm{p}<0.001$ Treated groups Vs Arthritic control

TABLE IX - Effect of formulation F4 on hematological parameters in FCA induced arthritic rats

\begin{tabular}{|c|c|c|c|c|c|c|c|c|}
\hline \multirow[b]{2}{*}{ Groups } & \multicolumn{2}{|c|}{ Hb (mg\%) } & \multicolumn{2}{|c|}{ 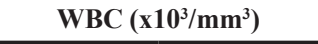 } & \multicolumn{2}{|c|}{$\mathrm{RBC}\left(\mathbf{x 1 0} / \mathbf{m m}^{3}\right)$} & \multicolumn{2}{|c|}{$\operatorname{ESR}(\mathbf{m m} / \mathbf{h})$} \\
\hline & $\begin{array}{c}\text { Before } \\
\text { treatment } \\
\left(21^{\text {st }} \text { day }\right)\end{array}$ & $\begin{array}{c}\text { After } \\
\text { treatment } \\
\left(42^{\text {nd }} \text { day }\right)\end{array}$ & $\begin{array}{c}\text { Before } \\
\text { treatment } \\
\left(21^{\text {st }} \text { day }\right)\end{array}$ & $\begin{array}{c}\text { After } \\
\text { treatment } \\
\left(42^{\text {nd }} \text { day }\right)\end{array}$ & $\begin{array}{c}\text { Before } \\
\text { treatment } \\
\left(21^{\text {st }} \text { day }\right)\end{array}$ & $\begin{array}{c}\text { After } \\
\text { treatment } \\
\left(42^{\text {nd }} \text { day }\right)\end{array}$ & $\begin{array}{c}\text { Before } \\
\text { treatment } \\
\left(21^{\text {st }} \text { day }\right)\end{array}$ & $\begin{array}{c}\text { After } \\
\text { treatment } \\
\left(42^{\text {nd }} \text { day }\right)\end{array}$ \\
\hline Normal control & $15.92 \pm 0.18$ & $16.38 \pm 0.15$ & $6.53 \pm 0.15$ & $6.85 \pm 0.12$ & $9.64 \pm 0.06$ & $10.22 \pm 0.20$ & $5.50 \pm 0.42$ & $5.16 \pm 0.40$ \\
\hline Arthritic control & $11.02 \pm 0.30^{\mathrm{a}}$ & $9.98 \pm 0.17^{\mathrm{a}}$ & $11.97 \pm 0.22^{\mathrm{a}}$ & $10.88 \pm 0.15^{\mathrm{a}}$ & $7.99 \pm 0.20$ & $6.31 \pm 0.14^{\mathrm{a}}$ & $34.67 \pm 1.22^{\mathrm{a}}$ & $42.83 \pm 1.35^{\mathrm{a}}$ \\
\hline Diclofenac sodium topical gel 1\% w/w & $11.23 \pm 0.21^{\mathrm{a}}$ & $14.97 \pm 0.26^{b}$ & $11.28 \pm 0.19^{\mathrm{a}}$ & $8.10 \pm 0.09^{b}$ & $7.36 \pm 0.25^{\mathrm{a}}$ & $8.86 \pm 0.21^{\mathrm{b}}$ & $38.17 \pm 0.83^{\mathrm{a}}$ & $27.17 \pm 2.02^{\mathrm{b}}$ \\
\hline Topical herbal gel formulation $2 \% \mathrm{w} / \mathrm{w}$ & $12.22 \pm 0.14^{\mathrm{a}}$ & $13.48 \pm 0.18^{\mathrm{b}}$ & $11.93 \pm 0.40^{\mathrm{a}}$ & $9.41 \pm 0.04^{\mathrm{b}}$ & $7.18 \pm 0.23^{\mathrm{a}}$ & $8.16 \pm 0.10^{\mathrm{b}}$ & $40.67 \pm 0.55^{\mathrm{a}}$ & $31.33 \pm 1.83^{b}$ \\
\hline
\end{tabular}

Data provided as mean \pm SEM $(n=6) ;{ }^{\mathrm{a}} \mathrm{p}<0.001$ Arthritic control Vs Normal control; ${ }^{\mathrm{p}}<0.001$ Treated groups Vs Arthritic control 
TABLE X -Effect of formulation F4 on biochemical parameters in FCA induced arthritic rats

\begin{tabular}{|c|c|c|c|c|}
\hline \multirow[b]{2}{*}{ Group } & \multicolumn{2}{|c|}{ Urea (mg/dL) } & \multicolumn{2}{|c|}{ Uric acid (mg /dL) } \\
\hline & $\begin{array}{c}\text { Before } \\
\text { treatment } \\
\left(21^{\text {st }} \text { day }\right)\end{array}$ & $\begin{array}{c}\text { After } \\
\text { treatment } \\
\left(42^{\text {nd }} \text { day }\right)\end{array}$ & $\begin{array}{c}\text { Before } \\
\text { treatment } \\
\left(21^{\text {st }} \text { day }\right)\end{array}$ & $\begin{array}{c}\text { After } \\
\text { treatment } \\
\left(42^{\text {nd }} \text { day }\right)\end{array}$ \\
\hline Normal control & $16.05 \pm 0.60$ & $16.42 \pm 0.59$ & $2.85 \pm 0.05$ & $2.91 \pm 0.07$ \\
\hline Arthritic control & $44.70 \pm 0.92^{\mathrm{a}}$ & $46.57 \pm 0.94^{\mathrm{a}}$ & $7.16 \pm 0.15^{\mathrm{a}}$ & $7.40 \pm 0.18^{\mathrm{a}}$ \\
\hline
\end{tabular}

Data provided as mean \pm SEM $(n=6) ;{ }^{a}<<0.001$ Arthritic control vs Normal control; ${ }^{b} p<0.001$ Treated groups Vs Arthritic control

concentration was observed in diclofenac sodium gel and herbal gel formulation F4 treated groups, when compared with the arthritic control group (Table X).

\section{Serum biomarkers}

In vitro determination of $C R P$

The serum of the tested animal groups before treatment showed agglutination and no agglutination was observed for the serum of groups treated with diclofenac sodium topical gel and topical herbal gel F4 formulation.

\section{In vitro determination of rheumatic factor}

Auto antibodies termed as "Rheumatoid Factor is the most useful prognostic marker for the diagnosis of rheumatoid arthritis, agglutination is used because greater sensitivity and simplicity. No agglutination was observed in the serum of the tested animal groups treated with diclofenac sodium topical gel and topical herbal gel F4 formulation.

\section{In vitro determination of $T N F-\alpha$}

TNF $\alpha$ level in arthritic induced rats was found to be $44.90 \mathrm{pg} / \mathrm{mL}$. The TNF $\alpha$ level of diclofenac sodium topical gel treated and topical herbal gel formulation F4 treated group was found to be less than the arthritic induced rats. Thus this study revealed that diclofenac sodium topical
TABLE XI - In vitro determination of serum TNF $\alpha$ level in FCA induced arthritic rats

\begin{tabular}{lc}
\hline Groups & TNF $\boldsymbol{\alpha}(\mathbf{p g} / \mathbf{m L})$ \\
\hline Normal control & $1.36 \pm 0.23$ \\
Arthritic control & $44.90 \pm 2.36^{\mathrm{a}}$ \\
Diclofenac sodium topical gel $1 \% \mathrm{w} / \mathrm{w}$ & $6.28 \pm 0.71^{\mathrm{b}}$ \\
Topical herbal gel formulation $2 \% \mathrm{w} / \mathrm{w}$ & $19.79 \pm 0.81^{\mathrm{b}}$ \\
\hline
\end{tabular}

All the values are mean $\pm \operatorname{SEM}(n=6) .{ }^{a} p<0.01$ arthritic control Vs normal control; ${ }^{b} \mathrm{p}<0.01$, treatment groups Vs arthritic control

gel and topical herbal gel formulation F4 treated groups reduced the levels of TNF $\boldsymbol{\alpha}$ (Table XI).

\section{In vitro determination of IL- $1 \beta$ and IL-6}

The cytokine levels was found to be increased in arthritic control, which was significantly $(\mathrm{p}<0.01)$ reduced in diclofenac sodium gel treated groups and herbal gel formulation treated groups (Table XII).

\section{Spleen and thymus weight}

The weights of spleen and thymus recorded after sacrificing the rats on $42^{\text {nd }}$ day. Significant $(p<0.01)$ reduction of spleen and thymus weight was observed for diclofenac sodium gel treated groups and herbal gel

TABLE XII - In vitro determination of serum Interleukin levels (IL-1ß and IL-6) in FCA induced arthritic rats

\begin{tabular}{lcc}
\hline \multirow{2}{*}{ Groups } & \multicolumn{2}{c}{ Serum interleukin $(\mathbf{p g} / \mathbf{m L})$} \\
\cline { 2 - 3 } & $\mathbf{I L - 1 \beta}$ & IL-6 \\
\hline Normal control & $1.38 \pm 0.24$ & $19.58 \pm 1.14$ \\
Arthritic control & $67.70 \pm 1.09^{\mathrm{a}}$ & $728.61 \pm 31.99^{\mathrm{a}}$ \\
Diclofenac sodium topical gel $(1 \% \mathrm{w} / \mathrm{w})$ & $20.99 \pm 0.60^{\mathrm{b}}$ & $313.95 \pm 14.66^{\mathrm{b}}$ \\
Topical herbal gel formulation $(2 \% \mathrm{w} / \mathrm{w})$ & $36.55 \pm 1.25^{\mathrm{b}}$ & $428.12 \pm 10.17^{\mathrm{b}}$ \\
\hline
\end{tabular}

Data provided as mean $\pm \operatorname{SEM}(\mathrm{n}=6) ;{ }^{\mathrm{a}} \mathrm{p}<0.01$, Arthritic control Vs Normal control; ${ }^{\mathrm{b}} \mathrm{p}<0.01$, Treatment groups Vs Arthritic control 
TABLE XIII - Effect of F4 formulation on thymus and spleen weight changes in FCA induced arthritic rats

\begin{tabular}{lcc}
\hline Group & Thymus weight $(\mathbf{g})$ & Spleen weight $(\mathrm{g})$ \\
\hline Normal control & $0.15 \pm 0.010$ & $0.58 \pm 0.011$ \\
Arthritic control & $0.65 \pm 0.009^{\mathrm{a}}$ & $1.33 \pm 0.064^{\mathrm{a}}$ \\
Diclofenac sodium topical gel $(1 \% \mathrm{w} / \mathrm{w})$ & $0.37 \pm 0.009^{\mathrm{b}}$ & $0.74 \pm 0.011^{\mathrm{b}}$ \\
Topical herbal gel formulation $(2 \% \mathrm{w} / \mathrm{w})$ & $0.43 \pm 0.007^{\mathrm{b}}$ & $0.89 \pm 0.015^{\mathrm{b}}$ \\
\hline
\end{tabular}

Data provided as mean $\pm \operatorname{SEM}(n=6) ;{ }^{a} \mathrm{p}<0.001$ Arthritic control Vs Normal control; ${ }^{b} \mathrm{p}<0.0001$ Treatment groups Vs Arthritic control

formulation F4 treated groups when compared with the arthritic control group (Table XIII).

Increase in serum levels of CRP, RF TNF- $\alpha$, IL1 $\beta$ and IL6 are characteristic features of RA (Feldmann, Manini, 2008) and hence, in vitro determination of serum biomarkers such as CRP, RF, TNF- $\boldsymbol{\alpha}$, IL1 $\beta$ and IL6 were performed for the arthritic control and all the treated groups. Significant inhibition of IL-1 $1 \beta$, TNF- $\alpha$ and IL-6 production, suggests that topical herbal gel formulation may have the potential to regulate pro-inflammatory cytokines which is in correlation with the reported literature (Choi, Lee, 2010).

\section{Histopathological examination}

Histological examination of normal specimen of joint showed normal joint space, normal adjacent soft tissue, synovium and cartilage (Figure 6A, 6B). Arthritis control specimen of joint showed with dense inflammation in the soft tissue around the joint. Specimen of joint of diclofenac sodium topical gel treated groups showed normal cartilage, cortex and marrow (Figure 6C, 6D). Histopathological examination of topical diclofenac sodium gel and topical herbal gel formulation F4 treated arthritic rats showed reduction in inflammation in the

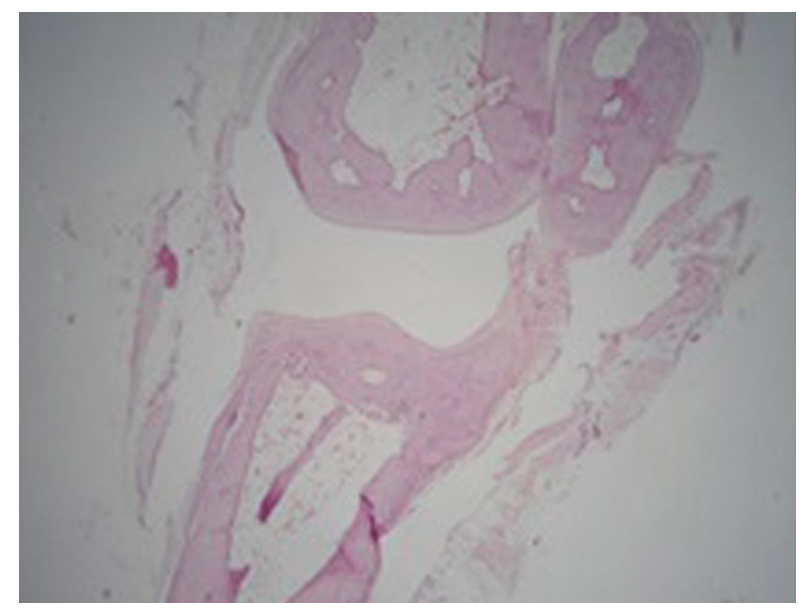

FIGURE 6A - Histopathological section of ankle joint of control group of rat under $10 \mathrm{X}$ showing normal joint surface. soft tissue around the joint when compared with arthritic control rats (Figure 6G, 6H).

\section{CONCLUSION}

Anti-arthritic activity of the developed topical herbal gel formulation may be due to the presence of luteolin and apigenin in methanol leaf extracts of Cardiospermum halicacabum and Vitex negundo (Sharififar, DehghnNudeh, Mirtajaldini, 2009). The developed formulation F4 consisting $2 \%$ each of CHME and VNME with $1.5 \%$ of carbopol 934 was found to be promising topical herbal gel for the treatment of arthritis. Further clinical studies can strengthen the use of this formulation for the patients suffering from joint inflammatory disorders.

\section{ACKNOWLEDGEMENT}

The authors are whole heartedly thank Defense Research and Development Organization, New Delhi for providing funds to carry out this research. The authors are also thankful to Chairman and Secretary of Kovai Medical Centre Research and Educational Trust, Tamilnadu for providing facilities necessary for carrying out the work.

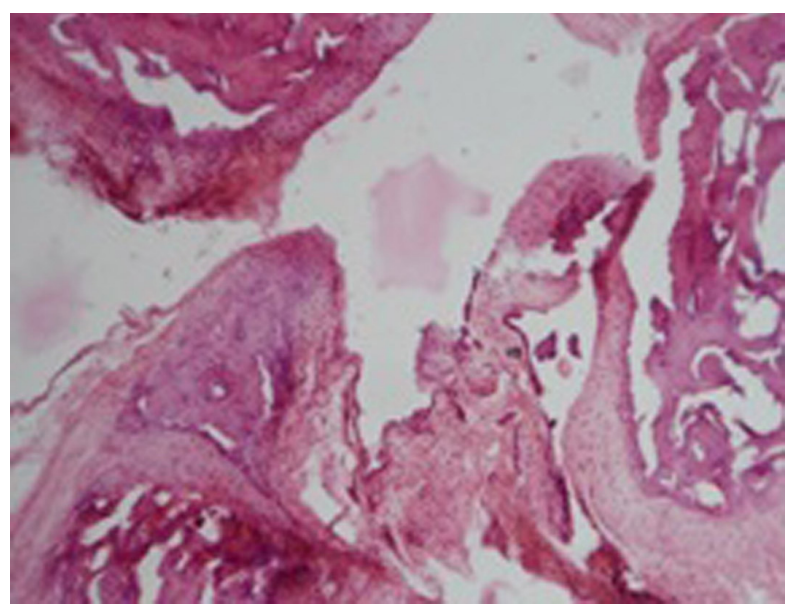

FIGURE 6C- Histopathological section of ankle joint of arthritic control group of rat under $10 \mathrm{X}$ showing inflammation. 


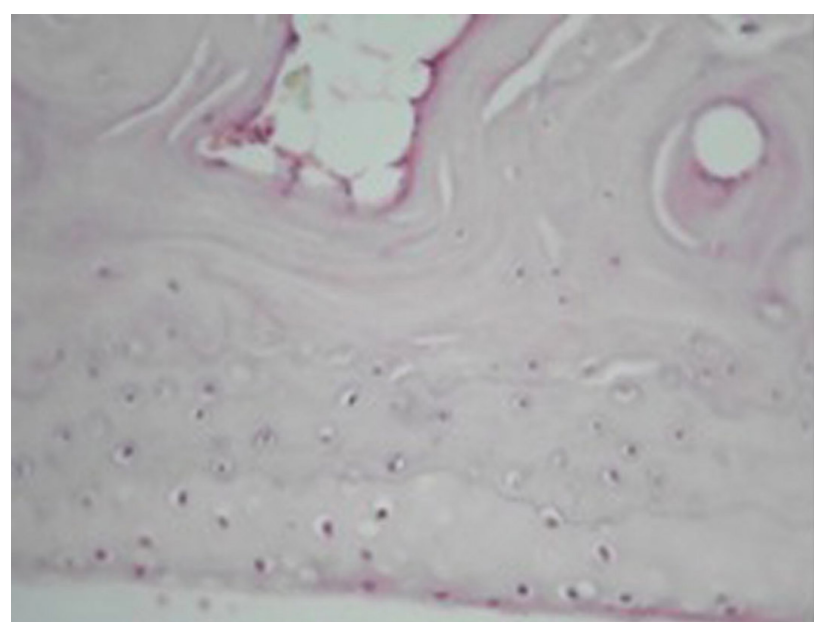

FIGURE 6B- Histopathological section of ankle joint of control group of rat under. $40 \mathrm{X}$ showing normal cartilage and cortex.

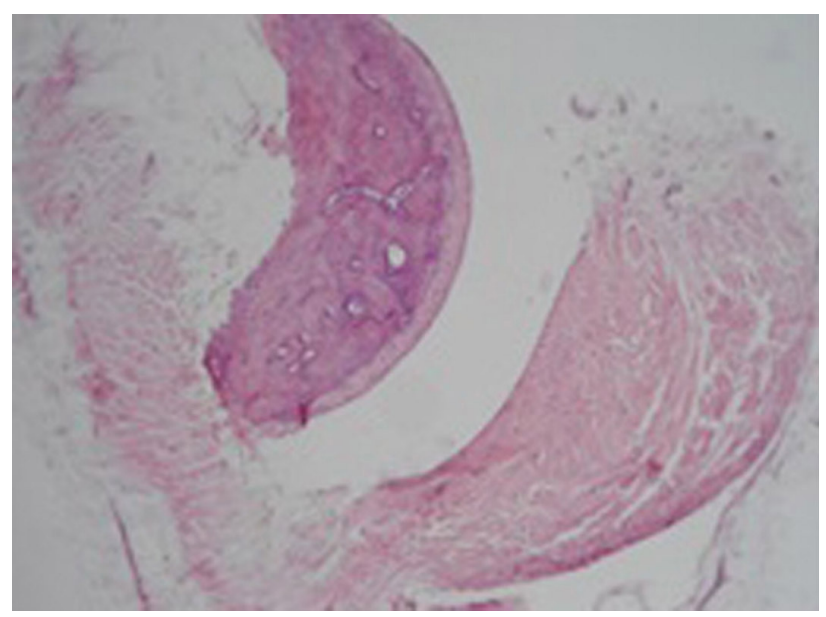

FIGURE 6E- Histopathological section of ankle joint of diclofenac gel treated group of rat under $10 \mathrm{X}$ showing normal cartilage and cortex and marrow.

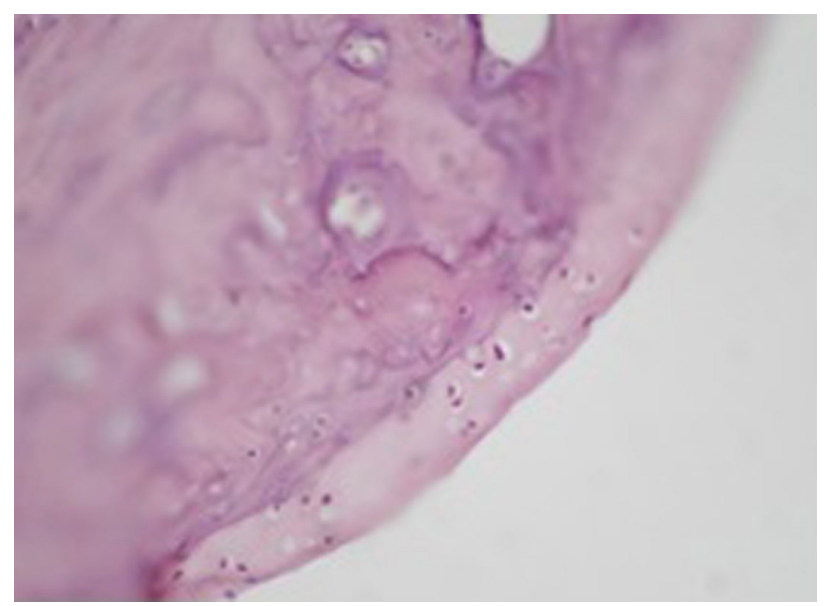

FIGURE 6F- Histopathological section of ankle joint of diclofenac gel treated group of rat under $40 \mathrm{X}$ showing normal cartilage and cortex and marrow.

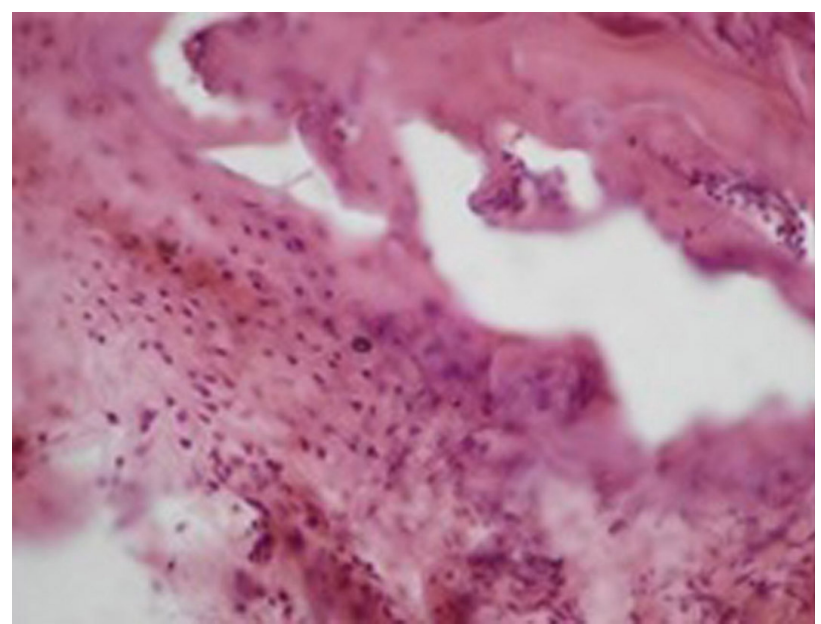

FIGURE 6D - Histopathological section of ankle joint of arthritic control group of rat under $40 \mathrm{X}$ showing inflammation.

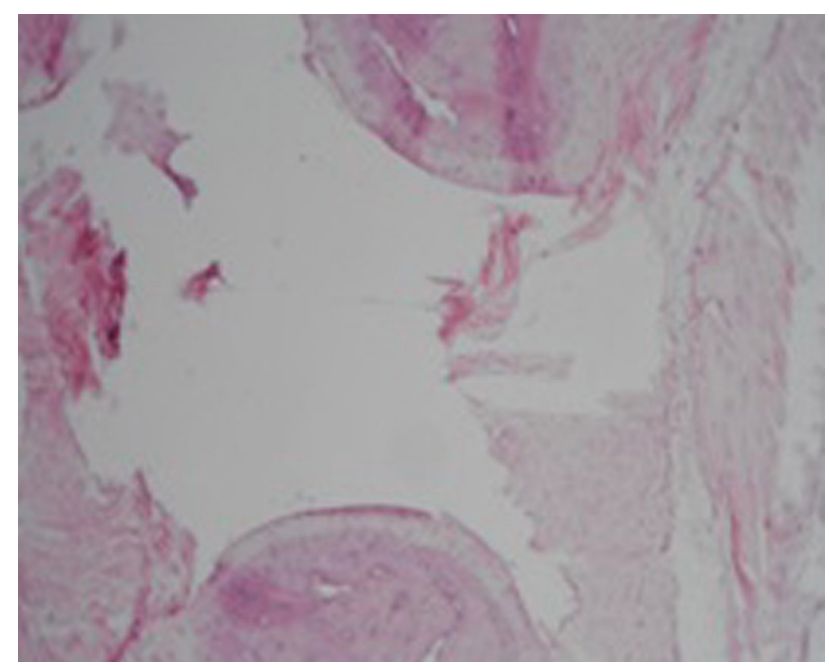

FIGURE 6G - Histopathological section of ankle joint of herbal gel treated group Of rat under $10 \mathrm{X}$ showing mild inflammation.

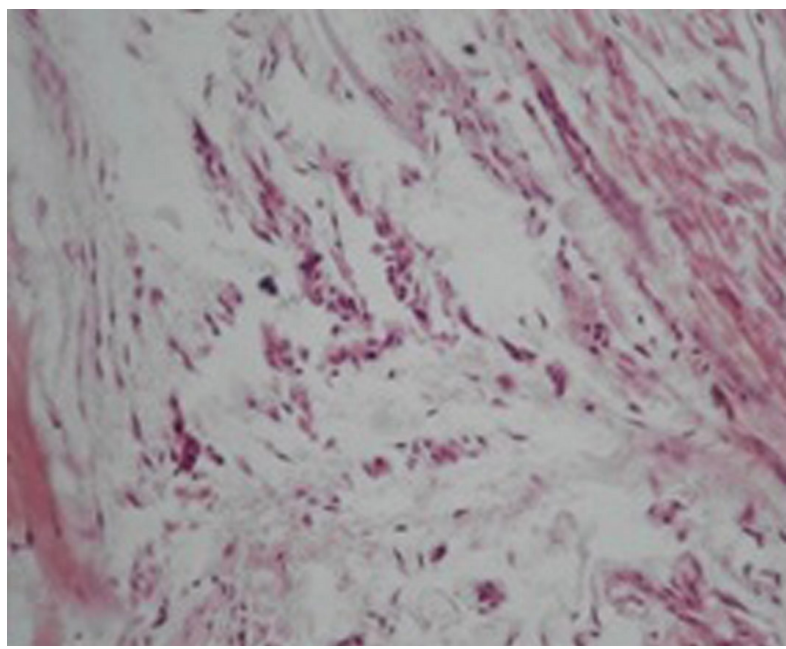

FIGURE 6H - Histopathological section of ankle joint of herbal gel treated group of rat under $40 \mathrm{X}$ showing mild .inflammation. 


\section{CONFLICT OF INTEREST}

Authors declare no conflict of interest.

\section{REFERENCES}

ASHA, V.V.; PUSHPANGADAN, P. Anti-pyretic activity of Cardiospermum halicacabum. Indian J. Exp. Biol., v.37, n.4, p.411-414, 1999.

BABU, K.C.V.; KRISHNAKUMARI, S. Cardiospermum halicacabum suppresses the production of TNF- $\alpha$ and NO by human peripheral blood mononuclear cells. Afr. $J$. Biomed. Res., v.9, p.95-99, 2006.

BLONCO-FLONTE, H.; ANGUIANO-IGEA S.; OTEROESPINAR, F.J.; BLANCOMENDEZ, J. In-vitro bioadhesion of carbopol hydrogel. Int. J. Pharm., v.142, p.169-174, 1996.

CHOI, E.M.; LEE, Y.S. Luteolin suppresses IL-1b-induced cytokines and MMPs production via p38 MAPK, JNK, NF-kappaB and AP-1 activation in human synovial sarcoma cell line, SW982. Food Chem. Toxicol., v.48, n.10, p.26072611, 2010.

FELDMANN, M.; MAINI, S.R. Role of cytokines in rheumatoid arthritis: an education in pathophysiology and therapeutics. Immunol. Rev., v.223, p.7-19, 2008.

GHOSH, M.N. Fundamentals of experimental pharmacology. Kolkatta: Scientific Book Agency, 1984. p.156-157.

GIINTER, S.; IRMARGD, M.; UTE, W.; CHISTOPH, M.S. Anticarcinogenic effects of the flavonoid luteolin. Molecules., v.13, n.10, p.2628-2651, 2008.

GOPALAKRISHNAN, C.; DHANANJAYAN, R.; KAMESWARAN, L. Studies on the pharmacological actions of Cardiospermum halicacabum. Indian J. Physiol. Pharmacol., v.20, p.203-206, 1976.

GUPTA, M.; MAZUMDER, U.K.; BHAWAL, S.R. CNS activity of Vitex negundo Linn in mice. Indian J. Exp. Biol., v.37, n.2, p.143-146, 1999.

JAIN, S.; PADSALG, B.D.; PATEL, A.K.; MOALE, V. Formulation development and evaluation of fluconazole gel in various polymer bases. Asian J. Pharm., v.1, p.6368, 2007.
JEYADEVI, R.; SIVASUDHA, T.; RAMESH KUMAR, A.; DINESH KUMAR, L. Anti-arthritic activity of the Indian leafy vegetable Cardiospermum halicacabum in Wistar rats and UPLC-QTOF-MS/MS identification of the putative active phenolic components. Inflamm. Res., v.62, n.1, p.115-26, 2013.

KIM, J.Y.; SONG, J.Y.; LEE, E.J.; PARK, S.K. Rheological properties and microstructures of carbopol gel network system. Colloid Polym. Sci., v.281, n.7, p.614-623, 2003.

KUMAR, E.; MASTAN, S.K.; AMRANDER REDDY, G.; RAGUNANDAN, N.; SREEKANTH, N.; CHAITANYA, G. Anti-arthritic property of the ethanolic leaf extracts of Cardiospermum halicacabum Linn. Biomed. Pharmacol. J., v.1, p.2, 2008.

KUMARAN, A.; KARUNAKARAN, R.J. Antioxidant activities of the methanol extract of Cardiospermum halicacabum. Pharm. Biol., v.44, n.2, p.146-151, 2006.

LAIRD, J.M.A.; CARTER, A.J.; GRAUERT, M.; CERVERO F. Analgesic activity of a novel use-dependent sodium channel blocker, crobenetine, immuno-arthritic rats, $B r . J$. Pharmacol., v.134, n.8, p.1742-1748, 2001.

LOGANATHAN, V.; MANIMARAN, S.; JASWANTH, A.; SULAIMAN, A.; SHIVAPRASADHA, R.M.V.; SENTHIL KUMAR, B.; RAJASEKARAN, A. The effects of polymers and permeation enhancers on releases of flurbiprofen from gel formulations. Indian J. Pharm. Sci., v.63 n.3, p.200-204, 2001.

MARTIN, A. Physical pharmacy, kinetics. First Indian reprint. New Delhi: B.I Waverly, 1994.

MIZUSHIMA, Y.; TSUKADA, W.; AKIMOTO, T. A Modification of rat adjuvant arthritis for testing antirheumatic drugs. J. Pharm. Pharmacol., v.24, n.10, p.781$785,1972$.

MURPHY, C.T.; MCCARROLL S.A.; BARGMANN, C.I.; FRASER, A.; KAMATH, R.S.; Genes that act downstream of DAF-16 to influence the lifespan of Caenorhabditis elegans. Nature, v.424, p.277-283, 2003.

NAIR, A.M.; SARAF, M.N. Inhibition of antigen and compound 48/80 induced contraction of guinea pig trachea by ethanolic extract of the leaves of Vitex negundo linn. Indian J. Pharmacol., v.27, n.4, p.230-233, 1995. 
NAIR, C.K.N.; MOHENAN, N. Medicinal plants in India with special reference to Ayurveda. Delhi, India: NAG Publisher, 1998.

NANDGUDE, T.; THUBE, R.; JAISWAL, N.; DESHMUKH, P.; CHATAP, V.; HIRE, N. Formulation and evaluation of $\mathrm{pH}$ induced in situ nasal gel of salbutamol sulphate. Int. J. Pharm. Sci. Nanotechnol., v.1, n.2, p.177-83, 2008.

NAPPINNAI, M.; PAKALAPATI S.; ARIMILLI R. Roficoxib gels-preparation and evaluation. Indian Drugs., v.43, p.513-15, 2006.

NAYAK, S.H.; NAKHAT, P.D.; YEOLE, P.G. Development and evaluation of cosmeceutical hair styling gels of ketoconazole. Indian J. Pharm.Sci., v.52, p.231-33, 2005.

NIELEN, M.M.; SCHAARDENBURG, D.V.; REESINK, H.W.; TWISK, J.W.R.; VAN DE STADT, R.J.; VANDER HORST, B.I.E.; DE KONING, M.H.; HABIBUW, M.R.; DIJKMANS, B.A. Simultaneous development of acute phase response and auto antibodies in preclinical rheumatoid arthritis. Ann. Rheum Dis., v.65, n.4, p.535$537,2006$.

PANIGRAHI, L.; GHOSAL, S.K.; PATTNAIK, S.; MAHARANA, L.; BARIK, B.B. Effect of permeation enhancers on the release and permeation kinetics of lincomycin hydrochloride gel formulations through mouse skin. Indian J. Pharm. Sci., v.68, p.205-11, 2006.

PATIL, K.R.; PATIL, C.R.; JADHAV, R.B. Antiarthritic activity of bartogenic acid isolated from fruits of Barringtonia racemosa Roxb. (Lecythidaceae). Evid. Based Complim. Alternat. Med., p.1-7, 2009.

QUEIROZ, M.B.R.; MARCELINO, N.B.; RIBEIRO, M.V.; ESPINDOLA, L.S.; CUNHA, F.; SILVA, M.V. Development of gel with Matricaria recutita L. extract for topic application and evaluation of physical-chemical stability and toxicity. Lat. Am. J. Pharm., v.28, n.4, p.574$579,2009$.

RA J A SEKARAN, A.; ARULKUMARAN, G .; ARIVUKKARASU, R. Acute and sub-acute toxicity study of methanol leaf extract of Cardiospermum halicacabum $\mathrm{L}$ and Vitex negundo L in rats. Pharmacog. Commun., v.5, n.1, p.39-45, 2015.
SHARIFIFAR, S.; DEHGHN-NUDEH, G.; MIRTAJALDINI, M. Major flavonoids with antioxidant activity from Teucrium polium L. Food Chem., v.112, n.4, p.885-888, 2009.

SHEEBA, M.S.; ASHA, V.V. Cardiospermum halicacabum ethanol extract inhibits LPS induced COX-2, TNF-alpha and iNOS expression, which is mediated by NF-kappa B regulation, in RAW264.7 cells. J. Ethnopharmacol., v.124, n.1, p.39-44, 2009.

SHEEBA, M.S.; ASHA, V.V. Effect of Cardiospermum halicacabum on ethanol induced gastric ulcers in rats. $J$. Ethnopharmacol., v.106, n.1, p.105-110, 2006.

SUBRAMANYAM, R.; NEWMASTER, S.G.; PALIYATH, G.; NEWMASTER, C.B. Exploring ethnobiological classifications for novel alternative medicine: a case study of Cardiospermum halicacabum L. (Modakathon, Balloon Vine) as a traditional herb for treating rheumatoid arthritis. Ethnobotany, v.19, p.1-18, 2007.

TAMHANKAR, C.P.; SARAF, M.N.; Anti-arthritic activity of Vitex negundo Linn. Indian J. Pharm. Sci., v.56, n.1, p.158-159, 1994.

TELANG, R.S.; CHATTERJEE, S.; VARSHNEYA, C. Studies on analgesic and anti-inflammatory activities of Vitex negundo Linn. Indian J. Pharmacol., v.31, p.363-366, 1999.

TSAI, C.C.; LIN, C.C. Anti-inflammatory effects of Taiwan folk medicine 'Teng-Khaia-U' on carrageenan and adjuvantinduced paw edema in rats. J. Ethnopharmacol., v.64, n.1, p.85-89, 1999.

WAAKO, P.J.; GUMEDE, B.; SMITH, P.; FOLB, P.I. The in vitro and in vivo anti-malarial activity of Cardiospermum halicacabum L. and Momordica foetida Schumch. J Ethnopharmacol., v.99, p.137-143, 2005.

WALKER, R.B.; SMITH, E.W. The role of percutaneous penetration enhancers. Adv. Drug Deliv. Rev. v.18, n.3, p.295-301, 1996.

Received for publication on $04^{\text {th }}$ September 2015 Accepted for publication on $03^{\text {rd }}$ May 2016 
